\title{
FISH-ASSEMBLAGE STRUCTURE OF THE CORUMBATAI RIVER BASIN, SÃO PAULO STATE, BRAZIL: CHARACTERIZATION AND ANTHROPOGENIC DISTURBANCES
}

\author{
CETRA, M. ${ }^{1}$ and PETRERE JR., M. ${ }^{2}$ \\ ${ }^{1}$ Departamento de Ciências Exatas e Tecnológicas - DCET/UESC, CEP 45650-000, Ilhéus, BA, Brazil \\ ${ }^{2}$ Departamento de Ecologia, Instituto de Biociências - UNESP, CEP 13506-900, Rio Claro, SP, Brazil \\ Correspondence to: Mauricio Cetra, Departamento de Ciências Exatas e Tecnológicas - DCET/UESC, \\ Rodovia Ilhéus-Itabuna, Km 16, CEP 45650-000, Ilhéus, BA, Brazil, e-mail: mcetra@uesc.br \\ Received August 29, 2004 - Accepted October 10, 2004 - Distributed May 31, 2006
}

(With 3 figures)

\begin{abstract}
The Corumbataí river is one of the main tributaries of the right margin of the Piracicaba river, itself a tributary of Tietê river. The Corumbataí is part of the Paraná river basin and is regionally important not only because of its good-quality water but also because the local landscape has unique features. This study aimed to characterize the fish assemblage of the Corumbataí in order to provide background data for evaluating its environmental status. For this purpose, within the Corumbatai river basin 4 of the main rivers were chosen, along which 3 sampling points each were established. Twenty-four samplings were carried out during March-July and September-December 2001. Diversity measures were used to evaluate biotic data. A linear ANCOVA model was used to test the hypothesis of a spatio-temporal variation in the fish assemblage, with species richness as the response variable, river order as the factor, and temperature and the natural logarithm of number of individuals as covariates. This analysis showed a spatio-temporal variation in agreement with various concepts, e.g., the specie-area relationship and the river continuum, which have been exhaustively discussed in the literature. When compared to those of the other rivers, data from the Ribeirão Claro river showed a different pattern, probably due to human interference, and exemplifying aquatic habitat fragmentation that might have led to isolation of local fish populations.
\end{abstract}

Keywords: Paraná river basin, Corumbataí river, fish assemblage, species diversity, habitat fragmentation.

\section{RESUMO}

\section{A estrutura das assembléias de peixes da bacia do rio Corumbataí, Estado de São Paulo, Brasil: caracterização e perturbações devido à atividade humana}

O rio Corumbataí é um dos principais tributários da margem direita do rio Piracicaba que é um tributário do rio Tietê. O rio Corumbataí integra a bacia do rio Paraná e é regionalmente importante não só por possuir águas de boa qualidade, mas também por possuir elementos raros na paisagem local. Este estudo visou caracterizar as assembléias de peixes do rio Corumbataí e fornecer dados que contribuam para uma avaliação da sua qualidade ambiental. Na bacia do rio Corumbataí, foram amostrados 4 rios principais, cada um com 3 pontos de coleta. Vinte e quatro amostras foram coletadas durante os meses de março a julho e de setembro a dezembro de 2001. Dados bióticos foram avaliados por medidas de diversidade. Um modelo linear ANCOVA foi utilizado para testar a hipótese de variação espaço-temporal nas assembléias de peixes, com a riqueza de espécies como variável resposta, ordem do rio como fator e temperatura e logaritmo natural do número de indivíduos como covariáveis. Esta análise mostrou uma variação espaço-temporal que é corroborada por conceitos exaustivamente discutidos na literatura, tais como relação espécie-área e o conceito de rio contínuo. Dados provenientes do rio Ribeirão Claro mostraram um padrão diferente quando comparados com os outros rios. Esta diferença foi provavelmente devido à interferência humana e atesta 
o processo de fragmentação de hábitats aquáticos que podem ter levado a um isolamento das populações locais de peixes.

Palavras-chave: bacia do rio Paraná, rio Corumbataí, assembléia de peixes, diversidade de espécies, fragmentação de hábitats.

\section{INTRODUCTION}

The study of biological assemblages is important not only for answering questions related to theoretical ecology, but also to identify organisms and/or emergent properties pertinent to environmental quality (Magurran, 1988). Such studies could supply background data for monitoring purposes and environmental conservation programs.

In addition, fish assemblages yield plentiful information about the life cycle of several species, food habit diversity, both alloctonous and autoctonous sources of energy, and to identification of species at the top of the food web (Harris, 1995).

Fish assemblage structures may be affected by zoogeographical patterns, local abiotic phenomena, biological attributes of given species, and biotic interactions among those comprising an assemblage (Matthews, 1998). Assemblages are also controlled by intrinsic factors (biological attributes of each species [Angermeier, 1982; Schlosser, 1987]) or, alternatively, by extrinsic factors, e.g., biotic and abiotic interactions among ecosystems (MarshMatthews \& Matthews, 2000).

This work focuses on the effects of extrinsic factors on emergent properties of a fish assemblage, with emphasis on spatio-temporal variation and responses of these assemblages to ongoing urbanization and changing land use in the Corumbatai river basin.

\section{MATERIAL AND METHODS}

The ca. $1690 \mathrm{~km}^{2}$ Corumbataí river basin comprises about $13 \%$ of the hydrographic basin of the Piracicaba, Jundiaí, and Capivari rivers. The study area is located between $47^{\circ} 30^{\prime}$ and $47^{\circ} 50^{\prime}$ west and $22^{\circ} 05^{\prime}$ and $22^{\circ} 30^{\prime}$ south (Fig. 1).

According to the Köppen classification, regional climate is Cwa, i.e., subtropical, dry in winter and rainy in summer, with annual mean temperature varying from between 20 and $23.7^{\circ} \mathrm{C}$ in January, and between 14.9 and $17.1{ }^{\circ} \mathrm{C}$ in July (ATLAS Ambiental..., 2002). Flow measurements of the basin's main river the (Corumbataí) reflect this climatic characteristic (Fig. 2).

The study area presents landscape features unusual in the interior of São Paulo, the state having Brazil's highest industrialization index. In 1996, the basins of the Piracicaba, Jundiaí, and Capivari rivers contributed $18.8 \%$ of the gross wealth generated by SP State's industries. Of the total pollution generated in Corumbataí basin, about 30\% derives from industrial activity, while sewage represents $\mathrm{ca}$. $70 \%$. Of the latter, $98 \%$ is collected, of which only $5 \%$ is treated.

The water quality of the Piracicaba river basin is presently at a critical state, while those of the Corumbataí river are of good quality. So much so that, despite its location on the margins of the Piracicaba river, the municipality of Piracicaba - through which the high water-volume river runs - obtains $100 \%$ of its water supply from the Corumbataí system.

Of the municipalities in the Corumbataí basin, that of Rio Claro - with ca. 163,000 inhabitants, or $79.5 \%$ of the basin's entire population - is the most important. It was estimated that of total water pollution generated by the municipality, $97 \%$ was sanitary sewage, while the remaining $3 \%$ was of industrial origin, making Rio Claro the main pollution source in the Corumbataí System (Atlas Ambiental, 2002).

The Ribeirão Claro river presents marked anthropic impacts, e.g., two dams: one - which had been used in the past for energy generation - in the lower stretch, and the other, in the middle stretch, for water abstraction despite sewage spillage along a roughly $3 \mathrm{~km}$ stretch of the river.

During the hydrological cycle of 2001, two samplings were carried out at 12 points: one sampling in March-June, and the other in September-December. The samplings were made in 4 main rivers of the basin: Passa Cinco, Cabeça, Corumbataí, and Ribeirão Claro (Fig. 1 and Table 1). Each sampling point consisted of a $150 \mathrm{~m}$ stretch and was located at a different altitude. 


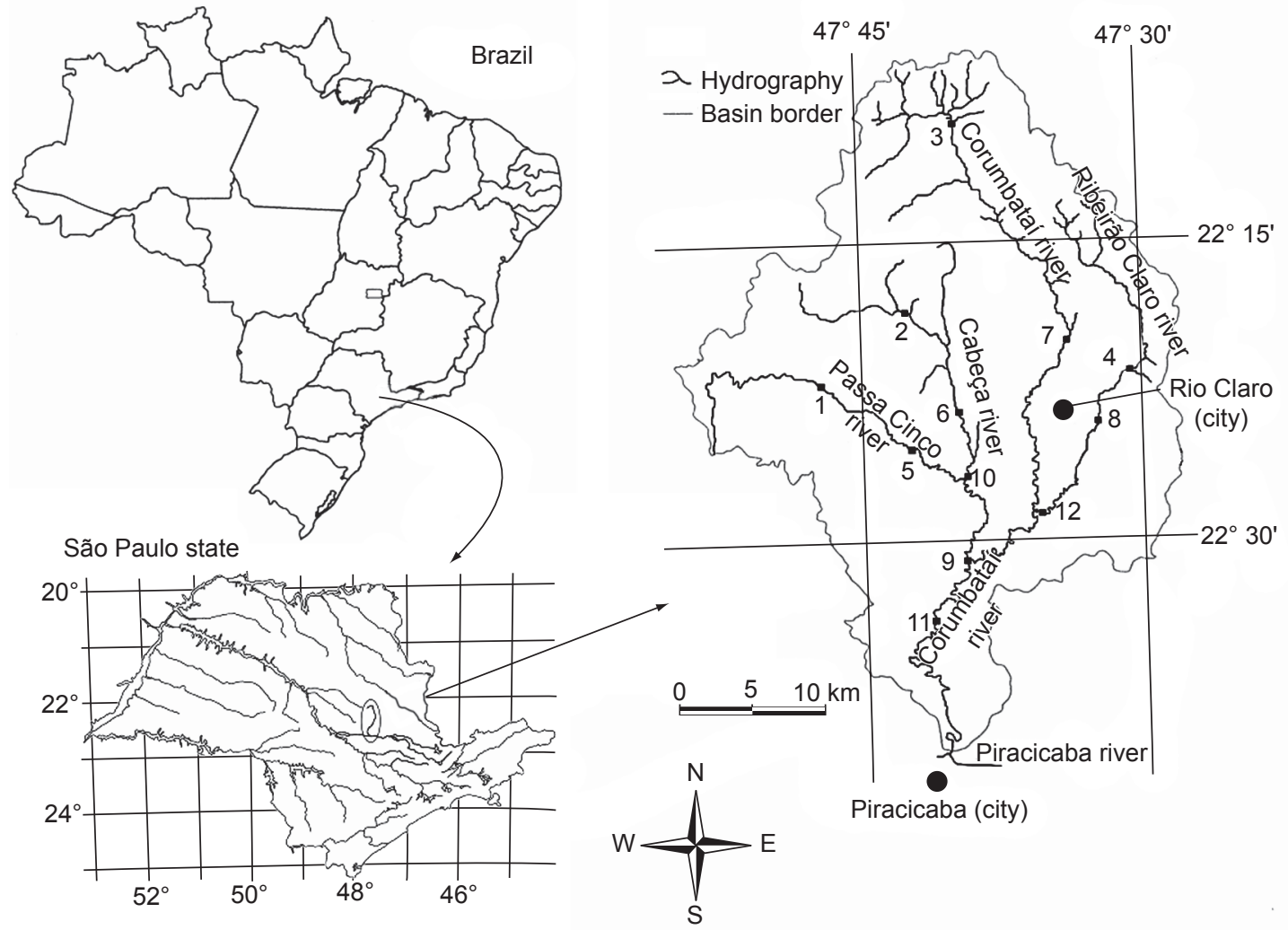

Fig. 1 - Geographical location of Corumbataí river basin with 12 sampling units (SUs): 1, 2, 3 (Passa Cinco river); 4, 5, 6 (Cabeça river); 7, 8, 9 (Corumbataí river); 10, 11,12 (Ribeirão Claro river).

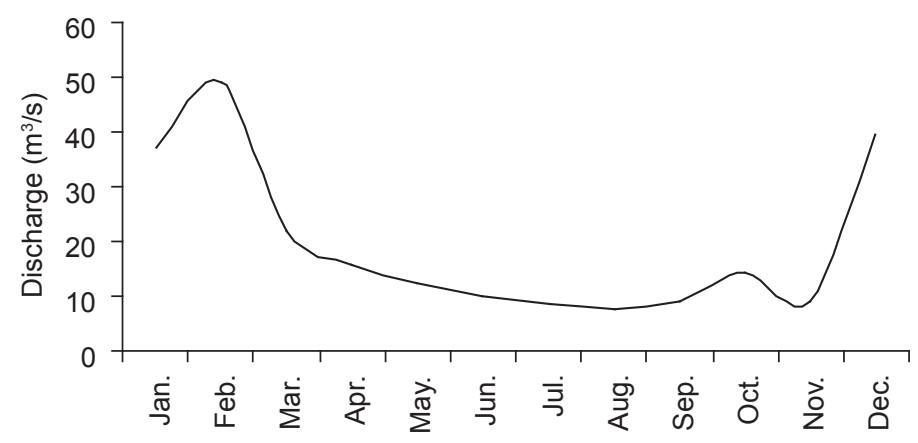

Fig. 2 - Mean monthly water discharge of Corumbataí river in 2001. Source: estação 4D-021/Recreio (22 $34^{\circ}$ S e $\left.47^{\circ} 41^{\prime} \mathrm{W}\right)$.

By using a map with a scale of 1:50,000, the points were hierarchically classified accordingly to position and order along the channel (see Horton, 1945, and Strahler, 1957, for protocols).
Samplings were carried out with a set of gillnets, with opposite knots and mesh size varying between 3 to $9 \mathrm{~cm}$, and 3 pairs of fish traps. The nets and traps were set by midafternoon (between 
TABLE 1

Hydrographic characteristics of the $\mathbf{4}$ main rivers of Corumbataí river basin.

\begin{tabular}{|l|c|c|c|c|}
\hline \multirow{2}{*}{ Characteristics } & \multicolumn{4}{|c|}{ River } \\
\cline { 2 - 5 } & Corumbataí & Passa Cinco & Ribeirão Claro & Cabeça \\
\hline Basin area $\left(\mathrm{km}^{2}\right)$ & 1710 & 525 & 291 & 211 \\
\hline River length $(\mathrm{km})$ & 110 & 60 & 43 & 28 \\
\hline Headstream altitude $(\mathrm{m})$ & 1058 & 1000 & 720 & 740 \\
\hline River mouth altitude $(\mathrm{m})$ & 470 & 480 & 520 & 520 \\
\hline
\end{tabular}

$15 \mathrm{~h}$ and $18 \mathrm{~h}$ ), and left until the following morning (between $7 \mathrm{~h}$ and $9 \mathrm{~h}$ ). Nets were placed and distributed randomly along the river margins in each sampling point. Pairs of traps were placed in convenient places along the channel.

The physiochemical parameters of the water, e.g., temperature, turbidity, dissolved oxygen, $\mathrm{pH}$, and conductivity were measured with a Horiba U-10 water quality checker.

Species were classified according to their food habits, i.e., herbivorous, bentonic, insectivorous, generalist, omnivorous, piscivorous, and detrictivorous. Species diversity was calculated with the Shannon index $\left(H^{\prime}=-\Sigma p_{i}^{*} \ln p_{i}, p_{i}=n_{i} / \Sigma n_{i}\right.$, $\mathrm{i}=1,2,3, \ldots \mathrm{s}$, where $\mathrm{s}$ is the number of species in the sample). The Morisita-Horn similarity coefficient was used to assess the similarity between species composition and between the trophic groups of the basin rivers studied.

The hypothesis of a difference in the spatiotemporal pattern and in the assemblage structure among these rivers was tested by analysis of covariance, in which the dependent variable was the number of species, and factor was the river order with three levels $(4,5$, and 6$)$, with temperature and the natural logarithm of number of individuals as covariates.

\section{RESULTS}

Along the entire basin of the Corumbataí river, 2474 individuals (with a summed weight approaching $56 \mathrm{~kg}$ ) belonging to 35 species were caught (Table 2). Twenty-two species (63\%) captured were Characiformes and $9(26 \%)$ were Siluriformes. Cyprinodontiformes (2 species, 6\%), Perciformes (1 species, $2.5 \%$ ), and Gymnotiformes (1 species, $2.5 \%$ ) were also represented. Characidae was the family with the highest number of species (12 species, 34\%), followed by Loricariidae
(4 species, 11\%), and Anastomidae (3 species, $8.5 \%)$.

Bryconamericus stramineus, Astyanax sp., Hypostomus strigaticeps, Astyanax altiparanae, Astyanax fasciatus, Serrapinnus notomelas, Astyanax scabripinnis, and Pimelodella gracilis represented about $80 \%$ of the total number of individuals captured. Eighteen small size $(\mathrm{L}<15 \mathrm{~cm})$ species were numerically overrepresented in the samplings $(\mathrm{ca} .75 \%)$. Besides being rare, Corydoras paleatus, Phalloceros caudimaculatus, Oligosarcus paranensis, and Poecilia vivípara were less than $5 \mathrm{~cm}$.

The highest points at Ribeirão Claro (sampling units 4 and 14) showed highest values, while the lower point (sampling units 11 and 24) showed the lowest Shannon diversity index values (Tables 3 and 4).

The fish assemblage of the Passa Cinco and Cabeça rivers showed the highest similarity in species composition when compared to that found in the Corumbataí and Ribeirão Claro (Table 5). The same pattern was observed for trophic classification, even though the fish assemblage of Ribeirão Claro was dissimilar when compared to that of any other river (Table 6).

The number of species caught increased significantly with river order $\left(n=24 ; r^{2}=0.208\right.$; $\mathrm{p}=0.025)$, water temperature $\left(\mathrm{n}=24 ; \mathrm{r}^{2}=0.151\right.$; $\mathrm{p}=0.061)$, and natural logarithm of the number of individuals $\left(\mathrm{n}=24 ; \mathrm{r}^{2}=0.465 ; \mathrm{p}=0.0002\right)$.

Besides its effect on the fishes' metabolism, the water temperature had a temporal effect because the temperature decreased significantly as the first twelve samplings were carried out $(n=12$; $r^{2}=0.663 ; p=0.001$ ), while during the last twelve samplings, temperature increased significantly $\left(\mathrm{n}=12 ; \mathrm{r}^{2}=0.634 ; \mathrm{p}=0.002\right)$. 
TABLE 2

Fish species; number of individuals $(\mathrm{N})$; and total length range $(\mathrm{L}(\mathrm{cm}))$.

\begin{tabular}{|c|c|c|}
\hline $\begin{array}{c}\text { Species } \\
\end{array}$ & $\mathbf{N}$ & $\mathbf{L}(\mathbf{c m})$ \\
\hline Bryconamericus stramineus Eigenmann, 1908 & 484 & $2.7-6.8$ \\
\hline Astyanax sp. & 437 & $3.0-8.8$ \\
\hline Hypostomus strigaticeps (Regan, 1908) & 350 & $3.5-31.0$ \\
\hline Astyanax altiparanae Garutti \& Britski, 2000 & 291 & $4.2-14.0$ \\
\hline Astyanax fasciatus (Cuvier, 1819) & 181 & $5.2-13.2$ \\
\hline Serrapinnus notomelas (Eigenmann, 1915) & 142 & $2.8-6.6$ \\
\hline Astyanax scabripinnis (Jenyns, 1842) & 103 & $2.5-8.4$ \\
\hline Pimelodella gracilis (Valenciennes, 1836 ) & 76 & $2.4-13.2$ \\
\hline Cyphocharax modestus (Fernández-Yépes, 1948) & 46 & $3.2-13.7$ \\
\hline Serrapinnus heterodon (Eigenmann, 1915) & 46 & 4.3-5.7 \\
\hline Cyphocharax nagelii (Steindachner, 1881) & 43 & $9.7-14.6$ \\
\hline Rhamdia quelen (Quoy \& Gaimard, 1824) & 40 & $4.9-29.9$ \\
\hline Hypostomus ancistroides (Ihering, 1911) & 39 & $9.5-19.2$ \\
\hline Hoplosternum littorale (Hancock, 1828) & 37 & $10.3-29.5$ \\
\hline Hoplias malabaricus (Bloch, 1794) & 27 & $11.4-40.9$ \\
\hline Geophagus brasiliensis (Quoy \& Gaimard, 1824) & 20 & $5.2-23.8$ \\
\hline Leporinus friderici friderici (Bloch, 1794) & 16 & $14.6-32.7$ \\
\hline Hyphessobrycon eques (Steindachner, 1882) & 16 & $2.9-3.8$ \\
\hline Salminus hilarii Valenciennes, 1850 & 13 & $18.3-37.2$ \\
\hline Characidium zebra Eigenmann, 1909 & 13 & $4.7-8.3$ \\
\hline Triportheus angulatus (Spix \& Agassiz, 1829) & 12 & $18.8-21.8$ \\
\hline Schizodon nasutus Kner, 1858 & 9 & $18.9-29.2$ \\
\hline Leporinus octofasciatus Steindachner, 1915 & 7 & $11.9-22.6$ \\
\hline Rineloricaria latirostris (Boulenger, 1900) & 6 & $12.0-19.2$ \\
\hline Prochilodus lineatus (Valenciennes, 1836) & 5 & $23.0-36.2$ \\
\hline Gymnotus carapo Linnaeus, 1758 & 3 & $19.8-29.4$ \\
\hline Serrasalmus spilopleura Kner, 1858 & 2 & $14.8-15.6$ \\
\hline Parodon nasus Kner, 1859 & 2 & $12.1-12.3$ \\
\hline Apareiodon piracicabae (Eigenmann, 1907) & 2 & $11.3-12.6$ \\
\hline Pimelodus maculatus Lacèpede, 1803 & 1 & 21.6 \\
\hline Hypostomus regani (Ihering, 1905) & 1 & 16.2 \\
\hline Oligosarcus paranensis Menezes \& Géry, 1983 & 1 & 4.6 \\
\hline Corydoras paleatus (Jenys, 1842) & 1 & 3.7 \\
\hline Poecilia vivipara Bloch \& Schneider, 1801 & 1 & 4.7 \\
\hline Phalloceros caudimaculatus (Hensel, 1868) & 1 & 4.5 \\
\hline Total & 2474 & - \\
\hline
\end{tabular}

When the natural logarithm of the number of individuals was plotted against species richness for the basin rivers, the expected pattern was not observed for the Ribeirão Claro river, i.e., increasing the sample size would be expected to increase the number of species captured. This exploratory analysis resulted in removal of those data from the ANCOVA.

About $78 \%$ of the variability in number of species in the basin can be explained by variation in space, represented as river order; time and physiology, represented by water temperature; and 
TABLE 3

Main characteristics of the sampling units (SU) of the Corumbataí river basin in March-June, 2001. PC: Passa Cinco river; CA: Cabeça river; CO: Corumbataí river; RC: Ribeirão Claro river. S: fish species richness; N: number of fish collected; H': Shannon diversity index; and DO: dissolved oxygen.

\begin{tabular}{|c|c|c|c|c|c|c|c|c|c|c|c|c|}
\hline & \multicolumn{12}{|c|}{ SU } \\
\hline & 1 & 2 & 3 & 4 & 5 & 6 & 7 & 8 & 9 & 10 & 11 & 12 \\
\hline River & $\mathrm{PC}$ & CA & $\mathrm{CO}$ & $\mathrm{RC}$ & PC & CA & $\mathrm{CO}$ & $\mathrm{RC}$ & CA & $\mathrm{PC}$ & $\mathrm{RC}$ & $\mathrm{CO}$ \\
\hline Stretch & high & high & high & high & middle & middle & middle & middle & low & low & low & low \\
\hline River order & 5 & 5 & 4 & 4 & 5 & 5 & 5 & 4 & 5 & 6 & 4 & 6 \\
\hline Altitude (m) & 627 & 613 & 636 & 600 & 565 & 563 & 574 & 571 & 537 & 523 & 563 & 466 \\
\hline$S$ & 12 & 5 & 6 & 9 & 8 & 9 & 9 & 7 & 7 & 4 & 6 & 11 \\
\hline $\mathrm{N}$ & 385 & 6 & 34 & 39 & 106 & 63 & 33 & 60 & 130 & 6 & 21 & 62 \\
\hline $\mathrm{H}^{\prime}$ & 2.19 & 2.25 & 1.98 & 2.87 & 2.34 & 2.68 & 2.79 & 1.83 & 1.49 & 1.92 & 1.34 & 2.33 \\
\hline Depth (m) & 1.07 & 1.03 & 1.07 & 1.40 & 0.77 & 1.35 & 1.53 & 1.00 & 1.25 & 0.88 & 2.00 & 1.15 \\
\hline Width (m) & 6.2 & 4.1 & 9.0 & 7.2 & 11.6 & 17.0 & 11.9 & 6.9 & 13.3 & 15.3 & 15.3 & 35.0 \\
\hline Water velocity $\left(\mathrm{m} \cdot \mathrm{s}^{-1}\right)$ & 0.74 & 0.93 & 0.78 & 0.72 & 1.00 & 0.61 & 0.78 & 0.22 & 0.52 & 1.02 & 0.15 & 0.47 \\
\hline Temperature $\left({ }^{\circ} \mathrm{C}\right)$ & 24.0 & 26.4 & 24.6 & 24.6 & 24.8 & 23.0 & 23.8 & 18.3 & 19.8 & 18.1 & 19.9 & 20.8 \\
\hline $\mathrm{DO}(\mathrm{mg} / \mathrm{L})$ & 7.8 & 10.3 & 10.3 & 10.2 & 10.4 & 11.2 & 10.1 & 9.3 & 9.2 & 9.4 & 5.2 & 6.9 \\
\hline
\end{tabular}

TABLE 4

Main characteristics of the sampling units (SU) of the Corumbataí river basin in September-December, 2001. PC: Passa Cinco river; CA: Cabeça river; CO: Corumbataí river; RC: Ribeirão Claro river. S: fish species richness; N: number of fish collected; H': Shannon diversity index; and DO: dissolved oxygen.

\begin{tabular}{|l|c|c|c|c|c|c|c|c|c|c|c|c|}
\cline { 2 - 15 } \multicolumn{1}{c|}{} & \multicolumn{10}{c|}{ SU } \\
\cline { 2 - 14 } \multicolumn{1}{c|}{} & $\mathbf{1 3}$ & $\mathbf{1 4}$ & $\mathbf{1 5}$ & $\mathbf{1 6}$ & $\mathbf{1 7}$ & $\mathbf{1 8}$ & $\mathbf{1 9}$ & $\mathbf{2 0}$ & $\mathbf{2 1}$ & $\mathbf{2 2}$ & $\mathbf{2 3}$ & $\mathbf{2 4}$ \\
\hline River & PC & RC & RC & CO & CA & PC & CA & CO & CA & PC & CO & RC \\
\hline Stretch & high & high & middle & high & high & middle & middle & middle & low & low & low & low \\
\hline S & 13 & 10 & 6 & 4 & 4 & 12 & 7 & 10 & 13 & 17 & 12 & 5 \\
\hline N & 375 & 32 & 13 & 16 & 53 & 354 & 53 & 247 & 89 & 122 & 105 & 70 \\
\hline H' & 2.58 & 3.16 & 2.35 & 1.53 & 0.92 & 1.28 & 2.22 & 1.67 & 3.19 & 2.84 & 2.76 & 1.13 \\
\hline Depth $(\mathrm{m})$ & 0.76 & 1.17 & 0.75 & 0.80 & 0.87 & 0.67 & 0.97 & 1.53 & 1.25 & 0.88 & 1.28 & 2.30 \\
\hline Width $(\mathrm{m})$ & 8.9 & 3.0 & 6.9 & 5.5 & 4.1 & 13.3 & 17.0 & 11.6 & 13.3 & 35 & 10.0 & 17.7 \\
\hline Water velocity $\left({\left.\mathrm{m} . \mathrm{s}^{-1}\right)}^{-1}\right)$ & 0.40 & 0.84 & 0.27 & 0.57 & 0.54 & 0.85 & 0.37 & 0.75 & 0.39 & 0.67 & 0.42 & 0.32 \\
\hline Temperature $\left({ }^{\circ} \mathrm{C}\right)$ & 18.1 & 20.5 & 21.7 & 21.2 & 24.1 & 25.2 & 22.7 & 22.6 & 26.2 & 29.7 & 26.6 & 24.4 \\
\hline DO $(\mathrm{mg} / \mathrm{L})$ & 9.17 & 8.25 & 7.67 & 8.69 & 7.99 & 9.85 & 10.86 & 8.37 & 7.74 & 7.31 & 7.66 & 6.27 \\
\hline
\end{tabular}

TABLE 5

Morisita-Horn similarity matrix between fish species composition of the Corumbataí river basin. PC: Passa Cinco river; CO: Corumbataí river; RC: Ribeirão Claro river; and CA: Cabeça river.

\begin{tabular}{|c|c|c|c|c|}
\cline { 2 - 5 } \multicolumn{1}{c|}{} & PC & CO & RC & CA \\
\hline PC & 1.0000 & - & - & - \\
\hline CO & 0.0103 & 1.0000 & - & - \\
\hline RC & -0.0654 & 0.1618 & 1.0000 & - \\
\hline CA & 0.5654 & 0.0240 & 0.06664 & 1.0000 \\
\hline
\end{tabular}


sample size, represented by natural logarithm of the number of individuals (Table 7 and Fig. 3).

\section{DISCUSSION}

The samplings carried out at the Corumbataí system are in agreement with the patterns found for
South American ichtyofauna (Schaefer, 1998) and for the upper basin of the Paraná river (Agostinho \& Júlio Jr., 1999; Castro \& Menezes, 1998), i.e., highest contribution of Characiformes, followed by Siluriformes, and a higher contribution $(75 \%)$ of small individuals $(\mathrm{L}<15 \mathrm{~cm})$ for the total sample (Table 2).

TABLE 6

Morisita-Horn similarity index matrix between fish species composition according to their trophic group in the Corumbataí basin rivers. PC: Passa Cinco river; CO: Corumbataí river; RC: Ribeirão Claro river; CA: Cabeça river.

\begin{tabular}{|c|c|c|c|c|}
\hline & PC & CO & RC & CA \\
\hline PC & 1.0000 & - & - & - \\
\hline CO & 0.0329 & 1.0000 & - & - \\
\hline RC & -0.2782 & -0.0223 & 1.0000 & - \\
\hline CA & 0.5517 & 0.2030 & -0.0167 & 1.0000 \\
\hline
\end{tabular}

TABLE 7

Analysis of covariance table with richness (S) as response variate. Factor: river order (RO); and covariates: water temperature $(W T)$ and logarithm of number of individuals $(\operatorname{lnN})\left(n=18 ; r^{2}=0.772\right)$.

\begin{tabular}{|c|r|r|r|r|c|}
\hline Source of variation & \multicolumn{1}{|c|}{ SS } & df & MS & F & p \\
\hline RO & 36.849 & 2 & 18.425 & 4.441 & 0.034 \\
\hline WT & 21.267 & 1 & 21.267 & 5.126 & 0.041 \\
\hline $\operatorname{lnN}$ & 103.851 & 1 & 103.851 & 25.033 & 0.000 \\
\hline Error & 53.931 & 13 & 4.149 & - & - \\
\hline
\end{tabular}

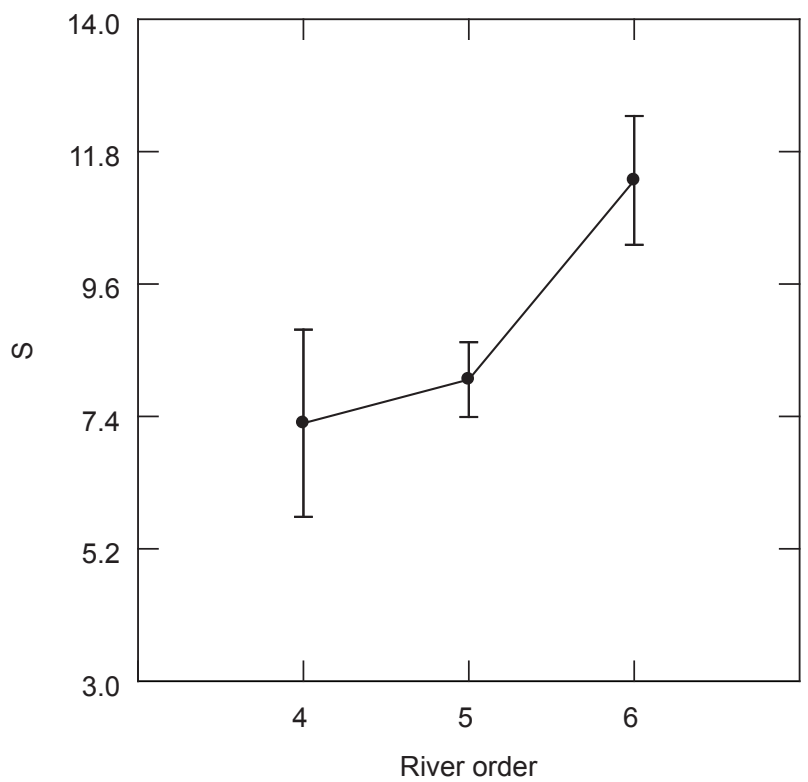

Fig. 3 - Adjusted mean number of species (S) according to river order calculated through analysis of covariance. 
The Ribeirão Claro river showed the highest dispersion of data related to channel depth, probably because the lower stretch (sampling units 11 and 24) in a reservoir. When compared with the other rivers, the Passa Cinco was characterized by low depth-values, i.e., shallow, and the highest superficial velocity. Because the Corumbataí is the main and the longest river in the basin, the sampling points were more distant from each other, which could explain the great variability observed in channel width. The Ribeirão Claro river showed the highest dispersion for turbidity values, low values for dissolved oxygen, and high values for conductivity. This pattern can be explained by the difference between the low stretch (sampling units 11 and 24), and that of the other two sampling points. This passage of the municipality of Rio Claro. The Passa Cinco river showed the lowest conductivity values, evidencing limpid waters (Tables 1, 3, and 4).

Increase in number of species as the order of the river increases has been observed for other systems (Angermeier \& Schlosser, 1989; Osborne \& Wiley, 1992), corroborating two main ecological concepts, i.e., the species-area relationship (MacArthur \& Wilson, 1967), as well as the river continuum concept (Vannote et al., 1980).

The temperature has a pervasive effect on organisms, especially in ectotherms such as fishes, since it regulates metabolic process intensities. An increase in metabolism means an increase in the energy needed, which determines the amount of food necessary for an organism to perform work. By the same token, a fish assemblage is also influenced by variations in the temperature, as shown by Magnuson et al. (1979). Besides representing the emerging properties of the fish assemblage, the water temperature represented its temporal dynamics.

The logarithm of the number of individuals was the variable that best predicted the number of species. This can be viewed either as a consequence of sample size or the effect of so-called "turnover noise", where the variation in species richness expected in a constant environment would depend on immigration rates due to great mobility of the fish and/or local extinction (Angermeier \& Schlosser, 1989).

The model best explaining spatio-temporal variation in the number of species of the Corumbataí river basin is that containing information about river order, temperature, and number of individuals, excluding the data for the Ribeirão Claro river for reasons previously mentioned.

River systems have many variables that control fish assemblages and, in the present work, adjusting a simple model allowed a good visualization of the multidimensional structure accounting for the spatio-temporal variation in the fish species richness in the Corumbataí river basin. Without the effect of the rivers the ANCOVA analysis explained about $77 \%$ of the variability of the number of species in the basin as a function of spatial variation, represented by river order; time and physiology, represented by water temperature; and sample size, represented by the natural logarithm of number of individuals (Table 7).

The fact that the model of spatio-temporal variation previously presented did not fit the Ribeirão Claro river data might be due to the simplicity of the model itself, which could not incorporate a landscape of the complexity of that through which this river runs. Because this model is compatible with continuum river theory, it cannot incorporate anthropic changes in the natural landscape. But a model must take into account the relationships of a river with its surroundings, i.e., the landscape, which in the present case is composed of patches connecting by corridors allowing contact among these habitats.

As anthropogenic activity fragments natural habitats, the results may have been, in the case of the Ribeirão Claro river, formation of metapopulations and disappearance of other populations that may subsequently reappear due to immigration from adjacent areas.

In any case, two causes might have led to the present situation: a) following adequate sewage treatment, specially by the municipality of Rio Claro, the high and medium stretches of the Ribeirão Claro river might be functioning as dispersal sources in recolonizing habitats along the basin channels; and b) lack of rehabilitation measures for rivers of the basin, mainly the basin of the Ribeirão Claro river, might have decreased in local population density within the metapopulation, jeopardizing their survival. Both of these possibilities illustrate the manner in which the fragmentation process in aquatic habitats can alter the species-area relationship 
(Schlosser, 1995), and fit the concepts of Punsey et al. (2000). However, it must be remembered that prior to present sewage treatment many species had already been distributed throughout the basin, which is small and presents low heterogeneity. In addition, micro and mesohabitat factors can affect the primary structure, i.e., species abundance, as is the case with the Ribeirão Claro river, which presently shows a high relative abundance and diversity (Tables 3 and 4).

The present results, although contributing to what is already known about spatio-temporal variation of the fish assemblage of the basin of the Corumbataí river, also were useful in detecting behavioral differences based on the data of the most impacted river of the basin, the Ribeirão Claro, disturbed as it is by sewage spillovers while crossing the municipality of Rio Claro, and by the degree of ichtyofauna isolation in points above the site at which water is abstracted. Unfortunately, the magnitude of this impact is not yet known, nor is it known for how long the fish assemblage can survive local environmental alterations.

\section{REFERENCES}

AGOSTINHO, A. A. \& JÚLIO JR, H. F., 1999, Peixes da bacia do alto Paraná. In: R. H. L., McConnell, (ed.). Estudos ecológicos de comunidades de peixes tropicais, Edusp.

ANGERMEIER, P. L., 1982, Resource seasonality and fish diets in an Illinois stream. Environmental Biology of Fishes, 4: $251-264$

ANGERMEIER, P. L. \& SCHLOSSER, I. J., 1989, Species-area relationships for stream fishes. Ecology, 70: 1450-1462.

ATLAS AMBIENTAL da bacia do rio Corumbataí, 2002, Available in: <http:// www.rc.unesp.br/igce/ ceapla/atlas> (15 May 2002).

CASTRO, R. M. C \& MENEZES, N. A., 1998, Estudo diagnóstico da diversidade de peixes do Estado de São Paulo. In: R. M. C., Castro, (ed.), Biodiversidade do Estado de São Paulo, Brasil: síntese do conhecimento ao final do século XX. 6 Vertebrados. WinnerGraph FAPESP.
HARRIS, J. H., 1995, The use of fish in ecological assessments. Australian Journal of Ecology, 20: 65-80.

HORTON, R .E., 1945, Erosional development of streams and their drainage basins: hydrophysical approach to quantitative morphology. Bull. Geol. Soc. Am., 56: 275-370.

MAC ARTHUR, R. H. \& WILSON, E. O., 1967, The Theory of Island Biogeography. Princeton University Press.

MAGNUSON, J. J., CROWDER, L. B., \& MEDVICK, P. A., 1979, Temperature as an ecological resource. American Zoologist, 19: 331-43.

MAGURRAN, A. E., 1988, Ecological diversity and its measurement. Croom Helm.

MARSH-MATTHEWS, E. \& MATTHEWS, W. J., 2000, Geographic, terrestrial and aquatic factors: which most influence the structure of stream fish assemblages in the Midwestern United States? Ecology of Freshwater Fish 9: 9-21.

MATTHEWS, W. J., 1998, Patterns in freshwater fish ecology. Chapman \& Hall.

OSBORNE, L. L. \& WILEY, M. J., 1992, Influence of tributary spatial position on the structure of warmwater fish communities. Canadian Journal of Fisheries and Aquatic Sciences, 49: 671-681.

PUNSEY, B. J., KENNARD, M. J., \& ARTHINGTON, A. H., 2000, Discharge variability and the development of predictive models relating stream fish assemblage structure to habitat in northeastern Australia. Ecology of Freshwater Fish, 9: 30-50.

SCHAEFER, S. A., 1998, Conflict and Resolution: Impact of New Taxa on Phylogenetic Studies of the Neotropical Cascudinhos (Siluroidei: Loricariidae). In: L. R., Malabarba, R. E., Reis, R. P., Vari, Z. M. S., Lucena and C. A. S., Lucena, (eds.), Phylogeny and Classification of Neotropical Fishes. EDIPUCRS.

SCHLOSSER, I. J., 1995, Critical landscape attributes that influence fish population dynamics in headwater streams. Hydrobiologia, 78: 71-81.

SCHLOSSER, I. J., 1987, The role of predation in age- and sizerelated habitat use by stream fishes. Ecology, 78: 651-659.

STRAHLER, A. N., 1957, Quantitative analysis of watershed geomorphology. Trans. Am. Geophys. Union, 38: 913-920.

VANNOTE, R. L., MINSHALL, G. W., CUMMINS, K. W., SEDELL, J. R., \& CUSHING, C. E., 1980, The river continuum concept. Canadian Journal of Fisheries and Aquatic Sciences, 37: 130-137. 